\title{
3 Abstract:
}

4 This paper is a reply to Esteve Corbera's critique of my earlier commentary on the economic valuation

I would like to thank Esteve Corbera for the careful reading of my commentary and for his thoughtful core to be more equitable, but also works to deepen the embedded nature of neoliberal ideology.

21 First, however, I feel it is important to address the issue of how justice is conceived and to clarify my

22 aim in writing the commentary. My intention was to provide a concise overview of motivations for

23 opposition to financialized conservation that are not grounded in intrinsic values for nature; my

24 intention was not to advance a particular framework conceptualization of justice within economic valuation. I presented a handful of important perspectives on valuation that are formulated, no doubt, by people with varied conceptions of what justice means. I did not intend to tease these apart, but rather to show that there are many who are motivated by some kind of concern for justice. The primary objective of the commentary, I stated, was to address the preoccupation of valuation advocates with the notion that extrinsic and intrinsic forms of valuation are compatible. This "compatibility argument", I explained, disregards a whole range of reasons - social justice reasons - that many remain cautious 
31 about the economic valuation of nature, whatever their particular conception of justice may be. This is

32 not a point with which Corbera has engaged.

34 Beyond this, Corbera and I approach the topic of economic valuation with very different objectives, 35 presenting the danger that we are largely talking past each other. Corbera seeks to make distinctions

36 between financialized conservation mechanisms, and he is unfazed by their use in cases where the

37 social or ecological outcomes are apparently positive. I, on the other hand, am concerned by the

38 implications that engaging such mechanisms has in the progression of capitalist ideals and mentalities

39 regardless of the immediate material outcomes. This presents a range of difficulties in making sense of

40 each others' perspectives. One important point of confusion is contained in the way we each talk about

41 valuation. In my usage, "valuation” does not necessarily refer to a formal research or policy process

42 that is making monetary values explicit, but rather to the general financialization of conservation

43 through the integration of capitalist economic structures and rationalities, part of what Smith (2007)

44 calls the "real subsumption of nature" to capital. It is a process that encompasses all aspects of the

45 recent trend of economically-oriented conservation (including PES, natural capital accounting,

46 offsetting, compensatory mitigation, or any other instrument that frames conservation in economic

47 terms) whether or not they ultimately result in abstracted ecosystem service commodities that may be

48 circulated in the economy.

50 A further distinction between our contributions lays in Corbera's optimistic view that certain types of

51 economic valuation can produce favorable social and ecological outcomes. Coming from the

52 perspective that valuation is ultimately about advancing capitalist forms of governance, I believe that it

53 will not just lead to the oversimplification of ecological complexity, but will further embed neoliberal

54 ideology. Corbera, on the other hand, takes the position that some forms, in certain circumstances, are 
acceptable. He utilizes Pirard's (2012) six-point typology of market-based instruments to distinguish

56 between mechanisms that "involve the trading of a right over an ecosystem service" and mechanisms

57 that "focus on changing the relative economic value of environmental goods" (Corbera this issue, pg , emphasis original). His suggestion is that the latter may avoid the pitfalls of full-blown

59 marketization, while asserting that I conflate PES with market-based conservation even though such ). This is one

61 place where our differing perspectives comes to bear on our understandings of "valuation", causing

62 Corbera to misunderstand my reservations. It is not simply the market-based nature of new

63 conservation mechanisms that I find troubling, but rather any means of conservation that conceives of

64 nature in monetary terms. As it is the act of applying economic language, logic, or mechanisms to

65 issues of conservation that I find problematic, I saw it unnecessary to explicate any typology of market-

66 based instruments for conservation. In my view, Pirard's "regulatory price signals" are as problematic

67 as his "tradable permits", "reverse auctions", or "Coasean-type agreements", since they reduce socio-

68 ecological complexity to simple monetary values.

69

70 This perspective is derived from my extensive research on Costa Rica's national PES program, which

71 certainly cannot be considered a "market" in any pure sense. As I have found, an assumption that state-

72 based financing is wholly distinct from market-based financing is misguided, as state revenue streams

73 are being re-designed to behave as markets through, for example, the introduction of user-fees (Matulis

74 2013; Matulis forthcoming). Further to this, McAfee and Shapiro (2010) describe Mexico's national

75 program as a hybrid, and though it exhibits a strong anti-market streak and is characterized by state

76 developmentalism, I argue that it still serves to embed the economic logic of monetary valuation, which

77 is a necessary condition for future marketization. Indeed, Shapiro-Garza indicates that recent political

78 developments have left Mexico's program more broadly exposed "to pressures from the World Bank to 
79 push for market formation" $(2013,13)$, strikingly similar to what has occurred in Costa Rica. Beyond

80 this, even in Vietnam's "highly centralized context", Pham et al. find "evidence to suggest that some

81 political space in decision making is given to nonstate actors" $(2014,22)$. It would be wrong to assume

82 that simply because a program does not exhibit ideal-type neoliberalism that it is not undergoing a

83 process of neoliberalization.

85 From my view, it matters rather little whether PES schemes are implemented as markets or "contractual 86 agreements". The danger is in the application of economic logic. Schemes that introduce monetary 87 values open conservation decision-making to the reductionism of simple accounting (regardless of 88 whether or not valuation is the entirety of the policy), exposing nature to the brutal logic of economic 89 rationality. Such valuation is not an appropriate means of recognizing the importance of ecological 90 systems to human survival.

92 At the same time that I condemn economic valuation for progressing neoliberalization, however, I

93 appreciate that local communities are not passive recipients of such policies and can actively resist the

94 elements they find objectionable. As Corbera suggests, there are cases where "traditionally

95 disadvantaged actors" have been able to "twist the rules [of these instruments] according to their

96 interests" (ibid., pg __ . The ability of affected communities to subvert unwelcome aspects, however,

97 is not a reason to accept a system that is fundamentally oriented towards the ideologies of

98 financialization, since it is these that are at the root of inequality. In my commentary, I take the

99 position that this mode of resource management should be disavowed, dismantled, and replaced by

100 something designed from its core to be more equitable. We should applaud communities for their

101 resistance to marketization, but go beyond this to repudiate the underlying ideology that Corbera

102 appears willing to tolerate. 
104 It is important to recognize that while capitalist forms of nature conservation remain "to a large extent

105 'non-performative' as an accumulation strategy" they are still "deeply performative in producing

106 political rationality" (Dempsey and Suarez, forthcoming). As Dempsey and Suarez argue, these

107 initiatives do a great deal to produce environmental actors "as entrepreneurial subjects" that are

108 "supposed to conduct themselves as businesses at every moment" (ibid.). The work that the economic

109 valuation of nature does may not (yet) be the production of actual markets, but it certainly is acting to

110 further embed a "neoliberal environmentality" (see Fletcher 2010). I agree with Corbera that value

111 alone will not render land, forests, or ecosystems investible, but valuation is about much more than

112 this; it is about instilling capitalist values in geographical imaginations and conducting the "complex

113 cultural work" (Li 2014, 592) that will make abstracted ecosystem service commodities possible.

115 Finally, I turn to what I see as the root cause of uneven development. Here, Corbera mischaracterizes

116 my understanding of why market-based conservation leads to injustice. He suggests that it is because

117 preexisting inequities produce uneven bargaining within markets and thus reproduce uneven results; "it

118 cannot lead to fair outcomes, since the original conditions are already unfair" (ibid., pg _ _). Actually,

119 my position is that markets - and the capitalist economic system more generally - produce uneven

120 geographical benefits regardless of prior conditions and in any case to which they are applied. This

121 position emerges from an appreciation of Neil Smith's foundational work explaining the nature of

122 capital and production of space (Smith 2008). Beyond simply exacerbating existing inequitable

123 conditions, capital actually produces them - that is, "uneven development is the hallmark of the

124 geography of capitalism" (Smith 2008, xiii). From this perspective, the task of critical scholars is not,

125 as Corbera suggests, to investigate the "conditions of income inequality" under which financialized

126 conservation unfolds (ibid., pg _ _ ), but rather it is in appreciating the internal logics and ideologies of 
127 the mechanisms themselves. The reason that people are selling ecosystem services - whether it is

128 "because they are very poor and have ... few income-generating options" or "because they think it is a

129 suitable option for their livelihoods" (ibid., __ ) - is somewhat irrelevant to the distributional

130 implications of selling ecosystem services.

131

132 Again, I appreciate that PES has in certain cases been "twisted" to achieve redistribution, but I question

133 the extent to which it (or any other mechanism that relies on the economic valuation of nature) may be

134 "acknowledged as [a] means to realize social justice" (Corbera this issue, ). A community's ability

135 to subvert market-oriented strategies and put them to use in a fundamentally different way is not at all

136 guaranteed. Indeed it is remarkable that this has been achieved in some cases in spite of the way the

137 mechanisms are designed. This is why I called for attention to be directed towards alternatives (e.g.

138 degrowth, recommoning, ethics-based management, a not-for-profit economy), as anything less than a

139 clean break from the existing system permits the continued progression of neoliberalization. The

140 economic valuation of nature simply expands the production of neoliberal subjects and deepens the

141 embedded nature of neoliberal ideology, as our environmental problems cannot be solved from within

142 the logics of capital, only (as Harvey 2014 makes abundantly clear) "moved around".

144 I thank Esteve for his engagement on this important topic, and I appreciate the contribution he has

145 made. As he points out, we agree that market and non-market instruments for the economic valuation

146 of nature are "related to a broader trend of neoliberal environmentalism" (ibid., pg __ ), and I endorse

147 his call to "deepen our understanding of the operational conditions and ethical principles governing"

148 such mechanisms (ibid., pg ___ I maintain my position, however, that the frameworks of the existing

149 capitalist system cannot ultimately be the means to greater justice and equity within the conservation of

150 nature. 


\section{Acknowledgments:}

153 I would like to thank the editor for inviting me to provide this reply. I am also grateful to Janet Fisher,

\section{References:}

CORBERA. Valuing Nature, Paying for Ecosystem Services and Realizing Social Justice: A response to Matulis (2014), this issue.

DEMPSEY, J. \& SUAREZ, D. Illiquid natures: the character of international 'for profit' biodiversity conservation, forthcoming.

FLETCHER, R. 2010. Neoliberal environmentality: Towards a poststructuralist political ecology of the conservation debate. Conservation and Society, 8, 171-181.

HARVEY, D. 2014. Seventeen Contradictions and the End of Capitalism, Oxford, Oxford University Press.

LI, T. M. 2014. What is land? Assembling a resource for global investment. Transactions of the Institute of British Geographers, 39, 589-602.

MATULIS, B. S. 2013. The narrowing gap between vision and execution: Neoliberalization of PES in Costa Rica. Geoforum, 44, 253-260.

MATULIS, B. S. Payments for Ecosystem Services, Neoliberalization, and the Internal Contradictions of Capital, forthcoming.

MCAFEE, K. \& SHAPIRO, E. N. 2010. Payments for Ecosystem Services in Mexico: Nature, Neoliberalism, Social Movements, and the State. Annals of the Association of American Geographers, 100, 579-599.

PHAM, T. T., DI GREGORIO, M., CARMENTA, R., BROCKHAUS, M. \& LE, D. N. 2014. The REDD+ policy arena in Vietnam: participation of policy actors. Ecology and Society, 19.

PIRARD, R. 2012. Market-based instruments for biodiversity and ecosystem services: A lexicon. Environmental Science \& Policy, 19-20, 59-68.

SHAPIRO-GARZA, E. 2013. Contesting the market-based nature of Mexico's national payments for ecosystem services programs: Four sites of articulation and hybridization. Geoforum, 46, 5-15.

SMITH, N. 2007. Nature as Accumulation Strategy. Socialist Register, 43, 16-36.

SMITH, N. 2008. Uneven Development: Nature, Capital, and the Production of Space, University of Georgia Press. 